\title{
Histological study on the possible protective effect of curcumin on potassium dichromate induced hypothyroidism in adult male albino rats
}

\section{Original Article}

\author{
Gihan Ibrahim Aboul-Fotouh, Rahma Kamal El- Din Abou El-Nour, Eman Abas \\ Farag, Wafaa Abd El-Azeem Abdou Boughdady
}

Department of Histology, Faculty of Medicine, Cairo University, Cairo, Egypt

\begin{abstract}
Introduction: Potassium dichromate, a widely used heavy metal in several industries induces hypofunction and tissue insult of the thyroid gland via oxidative stress. Curcumin; is a natural commonly used spice has a strong anti-inflammatory and antioxidant properties.

Aim of the work: To investigate the possible protective effect of curcumin on the hypothyroidism induced by potassium dichromate in albino rats.

Materials and Methods: Thirty- five adult male albino rats were divided into five groups, 15 rats in group I (control) and 5 rats in each of group II, III, IV and V. Group II (curcumin group) received curcumin orally (100 $\mathrm{mg} / \mathrm{kg} / \mathrm{bw}$ ) daily for 4 weeks. Group III (potassium dichromate induced hypothyroidism) received i.p injection of potassium dichromate $(2 \mathrm{mg} / \mathrm{kg} /$ bw) daily for 2 weeks. Group IV (recovery group) received potassium dichromate as group III then left untreated for another 2 weeks. Group V(curcumin and potassium dichromate group) received curcumin concomitant with potassium dichromate as in groups II and III, respectively daily for 2 weeks and only curcumin was continued for another 2 weeks. T3, T4 and TSH were assessed. Thyroid sections were subjected to toluidine blue, H\&E, PAS and PCNA immunohistochemical stains. Morphometric and statistical studies were done.

Results: Thyroid tissue insult and hypofunction with significantly decreased T3, T4 and increased TSH were detected in group III. Additionally, there was a significant increase in the mean values of follicular cell height, follicular diameter, mean number of PCNA positive nuclei and a significant decrease in the mean value of area percent of colloid versus group I, II and V with non-significant differences versus group IV. In group V, there was an obvious serological and histological improvement compared to group III and IV.
\end{abstract}

Conclusion: Curcumin had protective effect against hypothyroidism and thyroid tissue damage induced by potassium dichromate.

Received: 15 January 2018, Accepted: 23 January 2018

Key Words: Curcumin, hypothyroidism, PCNA, potassium dichromate, rat, thyroid.

Corresponding Author: Eman Abas Farag, Department of Histology, Faculty of Medicine, Cairo University, Cairo, Egypt, Tel.: 01140639636, E-mail: emanabas@kasralainy.edu.eg.

ISSN: 1110-0559, Vol. 41, No.2

\section{INTRODUCTION}

Hypothyroidism is the second most common endocrine disorder after diabetes, it is caused by under-activity of thyroid gland leading to deficiency of thyroid hormones below the normal level ${ }^{[1]}$. Acquired hypothyroidism can result from defects in mechanisms that control formation of thyroid hormones, or may arise as a complication during treatment of hyperthyroidism ${ }^{[2]}$. It is clinically linked with decreased metabolic rate which results in adverse effects on multiple organs and system activities ${ }^{[3]}$. Recently, several studies showed an increased production of reactive oxygen species (ROS) in hypothyroidism ${ }^{[4,5]}$.

Heavy metals, as chromium salts (Cr), could profoundly disrupt the function of the endocrine system. So, occupational exposure to toxic heavy metals as in mining and leather tanning renders the industrial workers with various health problems ${ }^{[6]}$. Occupational exposure to $\mathrm{Cr}$ is found among approximately half a million industrial workers worldwide. Also, chromium released from these industries into soil and water is the major route of chromium exposure for the general population ${ }^{[7,8]}$.

Chromium is detected in various oxidation states, the most common are trivalent $\mathrm{Cr}$ (III) and hexavalent $\mathrm{Cr}$ (VI) forms ${ }^{[9]}$. Hexavalent $\mathrm{Cr}$ (VI) as potassium dichromate (K2Cr2O7) is much more toxic than trivalent $\mathrm{Cr}$ (III) as it enters cells rapidly where it is reduced by intracellular reductants to short-lived chromium intermediates. This reduction process generates ROS, causing oxidative stress (OS) and damage in many systems ${ }^{[10]}$.

The medical uses of natural herbs are gradually 
increasing due to their anti-oxidant, anti-inflammatory, anti-bacterial and anti-cancer properties ${ }^{[11]}$. Curcumin is among the best known natural polyphenols. It is the major yellow pigment extracted from turmeric, a commonly used spice, derived from the rhizome of the herb Curcuma longa Linn $^{[12]}$. Curcumin exhibits hypolipidemic, antiinfectious, anticancer ${ }^{[13]}$, anti-inflammatory and antioxidant properties $^{[14]}$. Moreover, curcumin was reported as several times more potent than vitamin $\mathrm{E}$ as a free radical scavenger ${ }^{[15]}$ and to be pharmacologically safe for humans and animals with extremely good tolerance ${ }^{[16]}$.

Since, the hexavalent $\mathrm{Cr}$, potassium dichromate, is still widely used in several industries as min $\neg$ ing, chrome pigments, cement dust, dyes, leather tanning and as anticorrosive in cooking systems, stainless steel, and boilers ${ }^{[9,17]}$. And, several studies on rats showed hypofunction of the thyroid gland and thyroid tissue insult following exposure to $\mathrm{it}^{[18,19]}$. So, this study aimed to investigate the possible protective effect of curcumin on potassium dichromate induced hypothyroidism in adult male albino rats.

\section{MATERIALS AND METHODS}

\section{a) Drugs}

\section{1-Potassium dichromate.}

It was purchased from Sigma-Aldrich chemical company (Cairo, Egypt) in the form of a bottle containing $100 \mathrm{gm}$ of reddish powder, (Catalogue number 309176). The required daily dose (for the 5 rats of the group) was weighted, dissolved in $1 \mathrm{ml}$ distilled water and given by intra-peritoneal (i.p) injection at a dose of $2 \mathrm{mg} / \mathrm{kg} / \mathrm{bw}^{[6]}$.

\section{2 - Curcumin.}

It was purchased from Sigma-Aldrich chemical company (Cairo, Egypt) in the form of a bottle containing $10 \mathrm{gm}$ of yellow powder, (Catalogue number C1386). The required daily dose (for the 5 rats of the group) was weighted, suspended in $2 \mathrm{ml}$ corn oil and given orally through gastric gavage at a dose of $100 \mathrm{mg} / \mathrm{Kg} / \mathrm{bw}^{[20]}$.

\section{b) Animals}

This study was carried out in the animal house of Kasr El-Aini hospital. It included 35 adult male albino rats, weighted 160-200 gm. They were housed in standard stainless-steel cages under standard environmental conditions with free access to water and fed ad-libitium. They were treated in accordance with guidelines approved by the Animal Use Committee of Cairo University

\section{C) Experimental design}

Animals were divided into 5 groups.

- Group I (control group): $(\mathrm{n}=15)$. They were subdivided equally into 3 subgroups (Ia , Ib and Ic):

Subgroup Ia: Each rat was given $0.4 \mathrm{ml}$ corn oil (the solvent of curcumin) orally through gastric gavage daily for 4 weeks then rats were sacrificed with group II.

Subgroup Ib: Each rat was given i.p injection of $0.2 \mathrm{ml}$ distilled water (the solvent of potassium dichromate) daily for 2 weeks then rats were sacrificed with group III.

Subgroup Ic: Rats were given corn oil concomitant with distilled water in the same dose and route as in subgroup Ia and $\mathrm{Ib}$ respectively daily for 2 weeks and only corn oil was continued for another 2 weeks then rats were sacrificed with group V.

- Group II (curcumin group): $(\mathrm{n}=5)$, rats were given curcumin orally through gastric gavage at a dose of $100 \mathrm{mg}$ $/ \mathrm{kg} / \mathrm{bw}$, dissolved in $2 \mathrm{ml}$ corn oil daily for 4 weeks then sacrificed $^{[20]}$.

- Group III (potassium dichromate induced hypothyroidism): $(\mathrm{n}=5)$, rats were given i.p injection of potassium dichromate at a dose of $2 \mathrm{mg} / \mathrm{kg} / \mathrm{bw}$, dissolved in $1 \mathrm{ml}$ distilled water daily for 2 weeks then sacrificed to confirm hypothyroidism ${ }^{[6]}$.

- Group IV (recovery group): $(n=5)$, rats were given i.p injection of potassium dichromate in the same dose as in group III daily for 2 weeks and left untreated for another 2 weeks then sacrificed to assess the recovery from potassium dichromate treatment.

- Group V (curcumin and potassium dichromate group): $(n=5)$, rats were given curcumin simultaneously with potassium dichromate in the same dose and route as in group II and III respectively daily for 2 weeks and only curcumin treatment was continued for another 2 weeks then rats were sacrificed.

Just before sacrifice, tail vein blood samples were collected and thyroid function tests (free T3, free T4 and TSH) were measured by radioimmunoassay in Biochemistry Department, Faculty of Medicine, Cairo University.

Rats were then sacrificed under anaesthesia by i.p injection of Phenobarbital $(60 \mathrm{mg} / \mathrm{kg})^{[21]}$ and, a midline incision was done in the neck and sternohyoid and sternomastoid muscles were separated to expose the trachea. Trachea was traced upward until the thyroid gland was visible. Thyroid gland appeared as small reddish mass on each side of the trachea. The gland was dissected carefully to avoid its injury ${ }^{[22]}$. The collected thyroid glands were divided into 2 lobes:

The right lobes were processed for light microscopic study. Specimens were fixed in $10 \%$ buffered formalin solution for 48 hours, then processed to obtain Paraffin blocks. Paraffin sections 6 micrometers thick were cut and stained by:

$$
\begin{aligned}
& \text { - Hematoxylin \& eosin (H\&E) stain }{ }^{[23]} \text {. } \\
& \text { - Periodic Acid Schiff (PAS) stain }{ }^{[23]} \text {. }
\end{aligned}
$$

Proliferating cell nuclear antigen (PCNA) 
immunostaining: PCNA is a helper protein of DNApolymerase enzymes, necessary for DNA synthesis and is used as a standard marker for proliferating cells ${ }^{[24]}$. It is a rabbit polyclonal antibody (catalogue number ab15497, Abcam, Cambridge, UK). Immunostaining required pretreatment ${ }^{[25]}$, this was done by boiling for 10 minutes in $10 \mathrm{mmol} / \mathrm{l}$ citrate buffer (catalogue number AP 9003) (pH 6) for antigen retrieval and leaving the sections to cool in room temperature for 20 minutes. Then, the sections were incubated for one hour with the primary antibody. Immunostaining was completed by the use of Ultravision detection system (catalogue number TP - 015- HD). Counterstaining was done using Mayer's hematoxylin (catalogue number TA- 060- MH). Citrate buffer, Ultravision detection system and Mayer's hematoxylin were purchased from Lab Vision Thermo Scientific (Fremont, California, USA). Small intestine was used as a positive control sections. Positive reaction appeared as brown nuclear coloration. On the other hand, one of the thyroid sections was used as a negative control by passing the step of applying the primary antibody.

The left lobes were processed for preparation of semithin sections. The specimens were prefixed in $2.5 \%$ phosphate buffered glutaraldehyde for 3 hours, thereafter post-fixed in $1 \%$ osmium tetroxide in $0.1 \mathrm{M}$ phosphate buffer at $\mathrm{pH} 7.4$ and $4{ }^{\circ} \mathrm{C}$ for 2 hours. The fixed specimens were dehydrated and embedded in resin to cut semithin sections $(1 \mu \mathrm{m}$ thick) which were stained with $1 \%$ toluidine blue then examined by light microscope ${ }^{[26,27]}$.

\section{Morphometric study}

Only follicles in the center of the lobules were measured as they are the active follicles. It included measuring of:

- Height of follicular epithelium in H\&E. stained sections at a magnification of $x 400$.

- Diameter of thyroid follicles in H\&E stained serial sections at a magnification of $\mathrm{x} 100$.

- Area \% of colloid in PAS stained sections at a magnification of $\times 100$.

- Number of PCNA positive nuclei in PCNA immunostained sections at a magnification of $\times 400$.

All measurements were done in 10 non overlapping randomly chosen fields for each animal. Image analysis was done using " Leica Quin 500" software image analyzer computer system (Leica image system Ltd; Cambridge, England) present in the Histology department, Faculty of Medicine, Cairo University.

\section{Statistical analysis}

The morphometric and biochemical measurements were expressed as mean \pm standard deviation (SD) and were analyzed statistically using one-way analysis of variance ANOVA followed by "tuckey" post hoc test. Results were considered significant when $P$ value was $<0.05$. Calculations were made on SPSS software version 16 (SPSS Inc., Chicago, Illinois, USA) ${ }^{[28]}$.

\section{RESULTS}

\section{General observation:}

No deaths were observed in rats during the experiment.

All control subgroups (Ia, Ib and Ic) showed similar biochemical and histological results so, they were collectively named control group.

\section{Serological results and statistical analysis:}

The mean values of T3, T4 and TSH revealed non significant differences between group I (control group) and group II (curcumin group) and, between potassium dichromate induced hypothyroidism group (group III) and recovery group (group IV). Meanwhile, a significant decrease in the mean values of T3 and T4 and a significant increase in the mean value of TSH were detected in potassium dichromate induced hypothyroidism group (group III) and recovery group (group IV) versus control group (group I) and curcumin group (group II). On the other hand, there were a significant increase in the mean values of $\mathrm{T} 3$ and $\mathrm{T} 4$ and a significant decrease in the mean value of TSH in group V (curcumin and potassium dichromate group) versus potassium dichromate induced hypothyroidism group (group III) and recovery group (group IV). But these values were significantly different compared to control group (group I) and curcumin group (group II) "significant $P<0.05$ " (Table 1)

\section{Light microscopic results}

H\&E and toluidine blue stained (semithin) thyroid sections:

Sections from control group and curcumin group showed normal thyroid follicles of variable sizes, surrounded by blood capillaries and filled with colloid that appeared acidophilic with peripheral vacuolations in H\&E (Figs. 1a and 1d) ), and in semithin sections colloid appeared homogenous with variable densities and lacking vacuolations (Figs. 1b, 1c and 1e). The follicles were lined with a single layer of cubical follicular cells that had spherical vesicular nuclei with prominent nucleoli (Figs. 1a-1e) and parafollicular cells that appeared larger, paler and not reaching the lumen of the follicles (Figs. 1c and 1e).

Sections of potassium dichromate induced hypothyroidism group revealed marked histological alterations. Some follicles were enlarged in sizes and irregular in shapes. Multiple follicles had distorted walls with displacement of desquamated epithelial cells in their lumens. Follicular cells varied from cuboidal to flatten and 
most of the cells had vacuolated cytoplasm and rounded or flat dark irregular nuclei. Some follicles were partially lined with multiple cellular layers. Some follicles appeared partially collapsed. Congested blood vessels were found in the interfollicular tissue (Figs. 2a-2d) and mast cells with their specific metachromatically stained granules were frequently noticed in the interfollicular tissue nearby these vessels (Fig. 2d).

Thyroid sections from the recovery group demonstrated widely separated thyroid lobules. Desquamated epithelial cells were frequently noticed in the lumen of some follicles. The follicles were lined mostly with follicular cells with dark nuclei and vacuolated cytoplasm. Some follicles were lined with flattened cells with flattened dark nuclei. Some follicles were partially lined with multiple cellular layers (Figs. 3a-3c). Disruption in follicular wall was also detected (Figs. $3 b$ and 3.c).

Thyroid sections of curcumin and potassium dichromate group stained with H\&E (Fig. 3.d) and toluidine blue (Figs. 3e and 3f) showed apparently normal histological features except for the presence of some cells with dark nuclei and vacuolated cytoplasm in few follicles.

\section{Periodic Acid Schiff (PAS) stained thyroid sections:}

Sections of control group and curcumin group revealed prevalent PAS positive reaction in the colloid and the basement membranes of thyroid follicles and PAS negative reaction in the peripheral vacuolations of colloid (Figs. 4a and 4b). On the other hand, thyroid sections of potassium dichromate induced hypothyroidism group and recovery group demonstrated multiple follicles with widespread PAS negative reaction in the large colloid vacuolations and PAS positive reaction in the remained colloid. PAS positive reaction was also detected in the basement membranes of most follicles and discontinuous PAS positive reaction was detected in the basement membranes of disrupted follicles (Figs. $4 \mathrm{c}$ and $4 \mathrm{~d}$ ). Sections of curcumin and potassium dichromate group were comparable to control group (Fig. 4e).

\section{Immunohistochemical results of PCNA immunostained sections:}

Sections of the control group and curcumin group revealed PCNA positive immunoreaction that appeared as brown nuclear deposits in few follicular and interfollicular cells (Figs. 5a and 5b). On the other hand, widespread PCNA positive immunoreactivity was detected in the follicular and interfollicular cells in potassium dichromate induced hypothyroidism group (Fig. 5c) and in recovery group (Fig. 5d). Concerning curcumin and potassium dichromate group, few positive nuclei in follicular and interfollicular cells were demonstrated (Fig. 5e).

\section{Morphometric results:}

The mean values of both follicular diameter and follicular cell height in H\&E stained thyroid sections as well as, the mean numbers of PCNA positive nuclei in PCNA immune-stained sections of control group and curcumin group revealed non significant difference versus each other. These values increased in potassium dichromate induced hypothyroidism group and recovery group with a significant increase versus control group and curcumin group and a non significant difference versus each other. On the other hand, these values showed a significant decrease in curcumin and potassium dichromate group (group V) versus potassium dichromate induced hypothyroidism group and recovery group and a non significant difference versus control group and curcumin group (Table 2).

The mean values of area percent of colloid in PAS stained thyroid sections revealed non significant difference between control group and curcumin group. This value in potassium dichromate induced hypothyroidism group and recovery group recorded a significant decrease versus control group and curcumin group and a non significant difference versus each other. While in curcumin and potassium dichromate group, this value showed a significant increase versus potassium dichromate induced hypothyroidism group and recovery group and a non significant difference versus control group and curcumin group (Table 2).

Table 1: Mean values \pm SD of T3, T4 and TSH in all studied groups:

\begin{tabular}{lccc}
\hline Groups & T3 $(\mu \mathrm{g} / \mathrm{ml})$ & $\mathrm{T} 4(\mathrm{ng} / \mathrm{ml})$ & TSH (IU/ml) \\
\hline Group I & $3.69 \pm .01$ & $3.21 \pm .33$ & $1.35 \pm .033$ \\
Group II & $3.71 \pm .02$ & $3.34 \pm .025$ & $1.38 \pm .032$ \\
Group III & $1.67 \pm .01^{* \#}$ & $1.40 \pm .038^{* \#}$ & $3.74 \pm .035^{* \#}$ \\
Group IV & $1.71 \pm .06^{* \#}$ & $1.42 \pm .023^{* \#}$ & $3.71 \pm .023^{* \#}$ \\
Group V & $3.17 \pm .08^{*}$ & $2.72 \pm .053^{*}$ & $1.79 \pm .023^{*}$ \\
\hline
\end{tabular}

*Significant $(\mathrm{P}<0.05)$ compared to groups I and II.

\# Significant $(\mathrm{P}<0.05)$ compared to group $\mathrm{V}$. 
Table 2: Mean values $\pm \mathrm{SD}$ of morphometric parameters in all studied groups:

\begin{tabular}{lccc}
\hline Groups & Mean follicular diameter in $\mu \mathrm{m}$ & $\begin{array}{c}\text { Mean follicular cell } \\
\text { height in } \mu \mathrm{m}\end{array}$ & $\begin{array}{c}\text { Mean area of colloid } \\
\text { positive nuclei }\end{array}$ \\
\hline Group I & $8.1 \pm 1.59$ & $7.3 \pm 2.27$ & $14.72 \pm 3.99$ \\
Group II & $8.1 \pm 1.64$ & $6.9 \pm 2.08$ & $14.23 \pm 4.02$ \\
Group III & $16.3 \pm 3.33^{*}$ & $14.39 \pm 3.55^{*}$ & $4.23 \pm 1.28^{*}$ \\
Group IV & $14.2 \pm .41^{*}$ & $11.98 \pm .38^{*}$ & $6.04 \pm 1.72^{*}$ \\
Group V & $8.6 \pm 2.1$ & $7.9 \pm 1.9$ & $11.21 \pm 2.03$ \\
\hline
\end{tabular}

* Significant $(\mathrm{P}<0.05)$ compared to groups I, II and V.


Fig. 1: Photomicrographs of sections in the thyroid gland of (a): Group I (control group) illustrating apparently normal thyroid follicles (F) lined with a single layer of cubical follicular cells exhibiting spherical vesicular nuclei (arrows) and filled with peripherally vacuolated acidophilic colloid (C). The follicles are surrounded by blood capillaries (bv) (H\&E, x400). (b): Control group (Toluidine blue, x400) \& (c): Control group (Toluidine blue, x1000), showing apparently normal thyroid follicles (F) lined with one layer of cubical follicular cells with vesicular spherical nuclei with prominent nucleoli (arrows). The follicles are filled with homogenous colloid of variable densities (C) and surrounded by blood capillaries (bv). Parafollicular cells (yellow arrows) are also seen in Fig. $\mathrm{c}$ as larger cells not reaching the lumen of the follicles with pale cytoplasm and large pale vesicular nuclei. (d): Group II (curcumin group) (H\&E, x400) illustrating apparently normal thyroid follicles (F) lined with cubical follicular cells with spherical vesicular nuclei (arrows) and filled with peripherally vacuolated acidophilic colloid (C). The follicles are surrounded by blood capillaries (bv). (e): Curcumin group (Toluidine blue, x1000) showing apparently normal thyroid follicles (F) lined with one layer of cubical follicular cells with vesicular spherical nuclei with prominent nucleoli (arrows). The follicles are filled with homogenous colloid of variable densities (C) and surrounded by blood capillaries (bv). Parafollicular cells (yellow arrow) are also seen as larger cells not reaching the lumen of the follicles with pale cytoplasm and large pale vesicular nuclei. 



Fig. 2: Photomicrographs of sections in the thyroid gland of group III (potassium dichromate induced hypothyroidism) demonstrating (a): Disrupted and fused thyroid follicles (F) with desquamated epithelial cells (D) in their lumen. Dark nuclei (arrow heads) and vacuolated cytoplasm (thin arrows) are seen in most of follicular cells in addition to, some flattened follicular cells with flat dark nuclei (curved arrow). Congested blood capillaries (bv) are also seen between the follicles (H\&E, x400). (b): Thyroid follicles lined with apparently enlarged follicular cells with dark nuclei (arrow heads) and highly vacuolated cytoplasm (thin arrows). A congested blood vessel (bv) is also seen between the follicles. Some follicles have diminished colloid (C) and others are nearly devoid of colloid and appear partially collapsed (star) (H\&E, x400). (c): A large thyroid follicle (F1) containing desquamated epithelial cells (D) in the lumen. Another disrupted follicle (F2) is partially lined with more than one layer of follicular cells (wavy yellow arrow). Dark nuclei (arrowheads) and cytoplasmic vacuolations (thin arrows) are seen in most of the follicular and interfollicular cells. Also, flattened follicular cells with dark flat nuclei are seen in the lining of some follicles (curved arrow) (Toluidine blue, X 400). (d): A mast cell (M) with coarse metachromatic granules nearby a congested blood vessel (bv). A follicle (F) has some follicular cells with flat dark nuclei (curved arrow) and a parafollicular cell is also seen (yellow arrow). Some of the lining follicular cells of the follicle and desquamated epithelial cells (D) exhibit vacuolated cytoplasm (thin arrows) and dark irregular nuclei (arrow heads) (Toluidine blue, X 1000). 

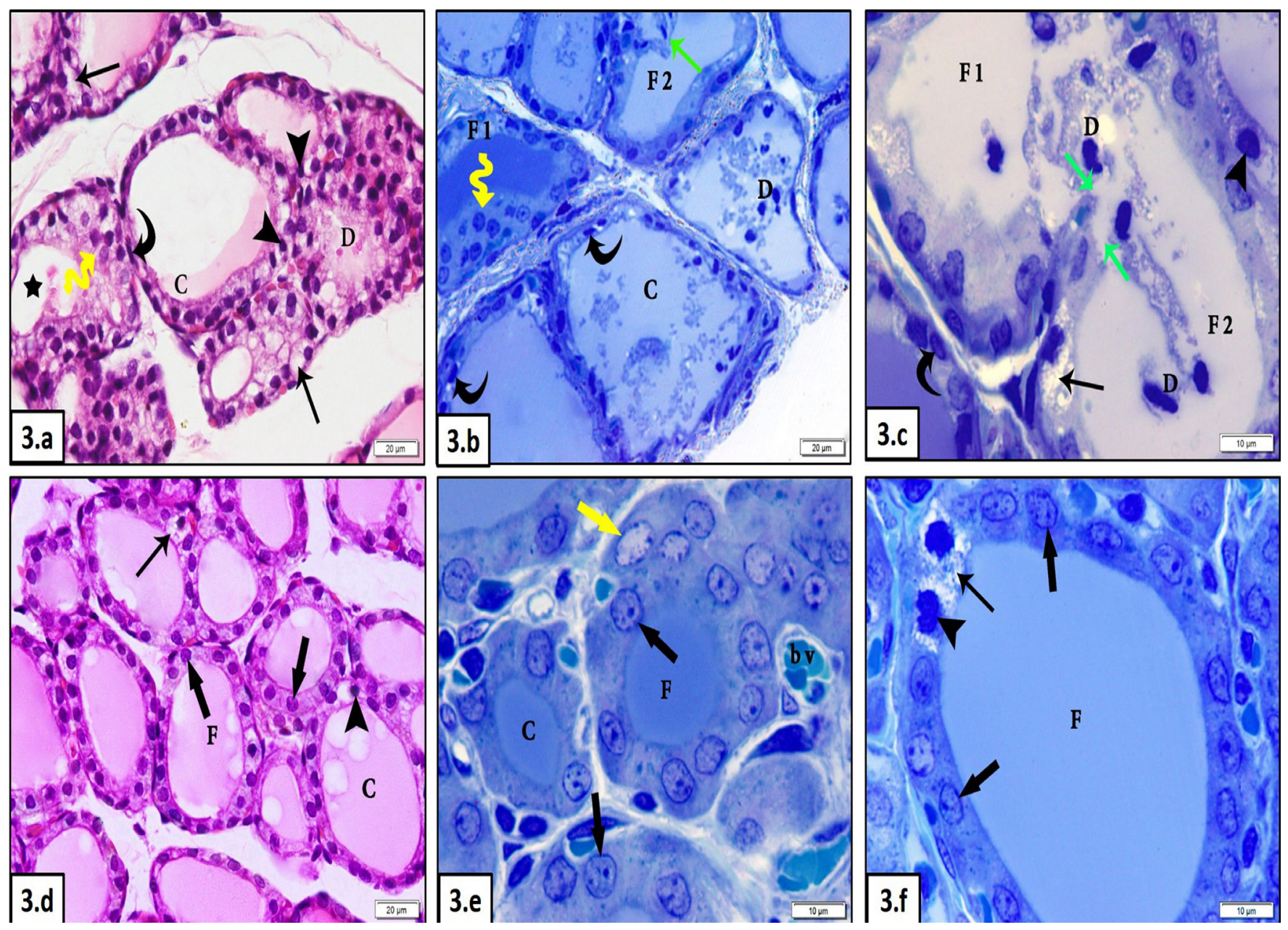

Fig. 3: Photomicrographs of sections in the thyroid gland of (a): Group IV (recovery group) showing a follicle with remnants of colloid (C), another follicle with nearly depleted colloid (star). Dark nuclei (arrow heads) and vacuolated cytoplasm (thin arrows) are seen in most of the follicular cells. Some flattened cells with flat dark nuclei (curved arrow) are also seen in some follicles. Thyroid follicle lined with multiple layers of vacuolated follicular cells is seen (wavy yellow arrow). Desquamated epithelial cells were also detected (D) (H\&E, $x 400)$. (b): Group IV demonstrating thyroid follicles filled with colloid (C), mostly lined with flattened cells with dark flattened nuclei (curved arrows). A follicle (F1) is partially lined with multiple cellular layers (wavy yellow arrow) that are encroaching on its lumen. There is disruption in the wall (green arrow) of another follicle (F2). Desquamated epithelial cells (D) are seen (Toluidine blue, X 400). (c): Group IV showing disruption of the walls (green arrows) of two thyroid follicles (F1 and F2) with their coalescence. Desquamated epithelial cells (D) are seen in their lumen. Some of the lining follicular cells exhibit dark nuclei (arrow head) and vacuolated cytoplasm (thin arrow). Some flat dark nuclei (curved arrow) are also seen in some follicular cells. (Toluidine blue, X 1000). (d): Group V (curcumin and potassium dichromate group) showing thyroid follicles (F) filled with acidophilic colloid (C) with peripheral vacuolations. Most of the lining follicular cells exhibit spherical vesicular nuclei (thick arrows). Few follicular cells have dark nuclei (arrow head) and vacuolated cytoplasm (thin arrow) (H\&E, $\mathrm{x}$ 400). (e): Group V revealing nearly normal thyroid follicles (F) filled with homogenous colloid (C) and lined with a single layer of follicular cells with vesicular spherical nuclei and prominent nucleoli (black arrows) and with parafollicular cells (yellow arrow). The follicles are surrounded by blood capillaries (bv) (Toluidine blue, X 1000). (f): Group V showing a thyroid follicle (F) mostly lined with follicular cells with vesicular spherical nuclei and prominent nucleoli (thick arrows). Few of the lining follicular cells exhibit dark irregular nuclei (arrow head) and vacuolated cytoplasm (thin arrow) (Toluidine blue, X 1000). 



Fig. 4: Photomicrographs of sections in the thyroid gland of (a): Group I (control group) and (b): Group II (curcumin group) showing widespread PAS positive reaction in the colloid (C) and in the basement membranes (arrow heads) of the thyroid follicles with negative reaction in the peripheral vacuoles of colloid (V). (c): Group III (potassium dichromate induced hypothyroidism group) and (d): Group IV (recovery group) illustrating multiple follicles with widespread PAS negative reaction in large colloidal vacuolations (V) and PAS positive reaction in the remaining colloid (C). Additionally, some follicles show PAS positive reaction in their intact basement membranes (arrowhead), discontinuous PAS positive reaction (arrow) in the disrupted basement membrane. (e): Group V (curcumin and potassium dichromate group) showing PAS positive reaction in the colloid (C) with negative reaction in the peripheral vacuoles (V). Also, PAS positive reaction is seen in the basement membranes of thyroid follicles (arrowheads).

(PAS, x 200) 

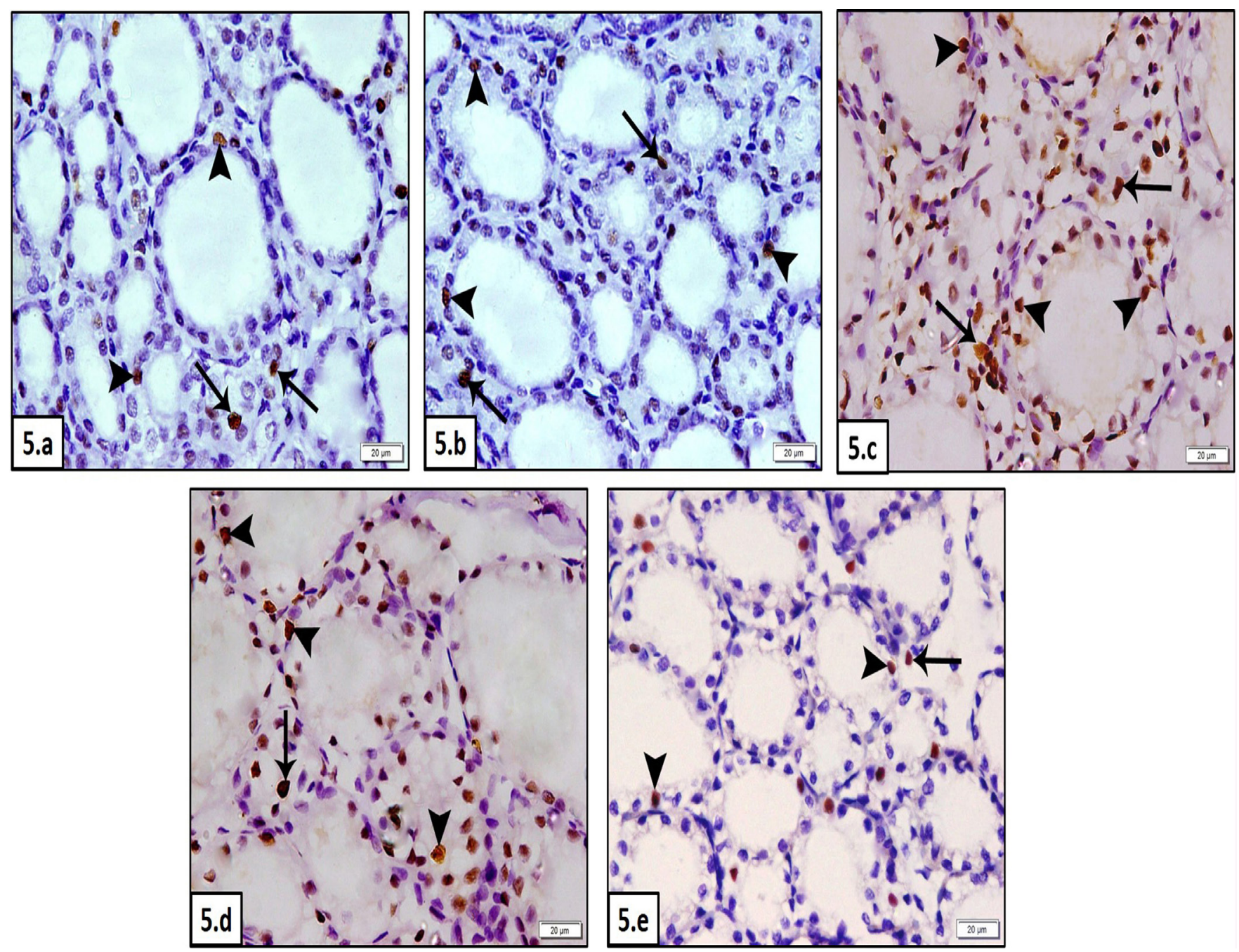

Fig. 5: Photomicrographs of sections in the thyroid gland of (a): Group I (control group) and (b): Group II (curcumin group) showing PCNA positive immunoreaction in the form of brown nuclear deposits in few follicular (arrowheads) and interfollicular cells (arrows). (c): Group III (potassium dichromate induced hypothyroidism) and (d): Group IV (recovery group) revealing numerous PCNA positive follicular nuclei in multiple follicles (arrowheads) and some PCNA positive interfollicular nuclei (arrows). (e): Group V demonstrating few PCNA positive follicular nuclei (arrowheads) in some follicles and few PCNA positive interfollicular nuclei (arrow).

(PCNA immunostaining, x400)

\section{DISCUSSION}

Hypothyroidism is one of the most common endocrine diseases mainly caused by disorders in the thyroid gland leading to decrease in production and secretion of the thyroid hormones ${ }^{[18,29]}$. In this study, potassium dichromate was chosen to induce hypothyroidism as it is a widely used heavy metal in several industries. It induced OS in many organs ${ }^{[30]}$ leading to various health hazards and occupational diseases ${ }^{[31,32]}$.

Several studies have found that polyphenolic compounds like curcumin can reduce or prevent oxidative damage caused by toxicants and oxidative materials $[33,34]$. Therefore, we aimed to evaluate the protective effect of curcumin on hypothyroidism and thyroid tissue damage induced by potassium dichromate in rats. Higher incidences of hypothyroidism were reported in female ${ }^{[35]}$, however, male rats were recruited in this study as males are more vulnerable to occupational exposure and to avoid the possible interfering effects of female hormones.

In the present study, the mean values of T3, T4 and TSH in the control group (group I) and curcumin group (group II) showed non significant differences. In addition, examined thyroid sections of curcumin group were more or less comparable to that of the control group. This was substantiated by morphometric analysis of follicular 
diameter, height of follicular cells and area percent of colloid which revealed non significant differences as compared to control group. These findings were consistent with the assumption that curcumin activity depends on the functional condition of the gland ${ }^{[20]}$.

Thyroid sections from our control group revealed normal histological architecture. The follicles at the periphery of the gland were larger than the central follicles with more colloid and few small peripheral vacuoles ${ }^{[36]}$. This pattern was previously described as normal histological features in rat thyroid and not in humans ${ }^{[37,38]}$. The peripheral follicles mainly serve as a pool of old hormone, whereas the smaller, centrally distributed ones are responsible for thyroid hormone secretion $^{[39]}$. Therefore, central follicles were chosen for morphometric measurements. Likewise, in toluidine blue stained semithin sections, the observed variable densities of colloid staining were correlated to and explained in a former study as variable follicular activities ${ }^{[40]}$ and absence of peripheral vacuoles might be explained by less liability of resin than paraffin to shrinkage during hardening and compression during sectioning ${ }^{[41]}$.

Potassium dichromate induced hypothyroidism (group III) revealed significant decrease in T3 and T4 and significant increase in TSH versus control group. Similar findings were reported by Hassanin et al ${ }^{[19]}$ who attributed impairment of thyroid hormones production by the follicular cells to increased OS and ROS that resulted during reduction of potassium dichromate to the trivalent form. Other researchers ${ }^{[9]}$ attributed the fall in $\mathrm{T} 3$ and T4 to active combination of chromium with globulins. This in turn, hindered the process of thyroglobulin proteolysis.

Consistent with the previously mentioned hormonal profile, sections of potassium dichromate induced hypothyroidism group revealed marked histological alterations compared to control group. Multiple follicles appeared degenerated with desquamated epithelial cells in their lumen. Some follicles appeared collapsed, some follicles had disrupted walls and appeared coalesced and other follicles were lined with multiple cellular layers. Cytoplasmic vacuolations and dark pyknotic nuclei were seen in most of the follicular and interfollicular cells. Multiple follicles showed either diminished colloid or depleted colloid. All these previous findings might be elucidated by potassium dichromate induced $\operatorname{OS}^{[19]}$ and by the highly elevated TSH level in this group ${ }^{[6]}$. Others attributed potassium dichromate cytotoxicity to a combination of mechanisms including DNA damage, caspase activation, mitochondrial dysfunction and formation of $\operatorname{ROS}^{[10]}$.

The majority of follicular cells in potassium dichromate induced hypothyroidism group appeared high cuboidal or columnar with significant increase in height versus control group. This might represent the early resistant stage of the gland in which thyroid follicles were under stress of the toxicant and were trying to cope with this condition by hypertrophy and even hyperplasia ${ }^{[9]}$. This was confirmed in the present work by a significant increase in the diameter of thyroid follicles compared to the control. Elevated TSH stimulates the follicles to synthesize and secrete more hormones into the circulation in an attempt to compensate for decreased thyroid hormones similar to what occurred with chronic iodine deficiency ${ }^{[42]}$. However, with continuation of stress, the gland became exhausted as confirmed in the same group by the presence of some follicles lined with flat cells with flat nuclei indicating hypoactivity. Previous investigators correlated follicular epithelium height to the functional state of the thyroid gland $^{[43]}$.

More reinforcement came from the extensively vacuolated or even depleted colloid encountered in most follicles in PAS stained sections from the same group and the significant decrease in mean area percent of colloid versus control. Follicular cells respond to elevated TSH with more rapid and continuous removal of thyroglobulin from the lumen of follicles in an attempt to compensate for decreased thyroid hormones in the blood leading to more vacuolations in colloid. But, endocytosis of colloid usually proceeds at a rate greater than synthesis resulting in progressive depletion of colloid ${ }^{[9]}$. Even with the trial of synthesis by cell and endocytosis of the colloid the net result is decreased level of T3and T4 versus control. In the same consequence, multiple thyroid follicles in the same group appeared irregular in shapes with disrupted basal laminae and wide interfollicular spaces. This finding might be related to degenerative changes and collapse of some follicles following colloid depletion ${ }^{[6]}$.

The shape of nuclei of follicular cells in the same group varied from spherical to flat corresponding to variation in the shape of cells. Most nuclei were irregular, darkly stained, and pyknotic denoting apoptosis and DNA damage caused by $\mathrm{OS}^{[44]}$. The induction of apoptosis by potassium dichromate in the thyroid of rats was confirmed in a former study ${ }^{[6]}$ by negative expression of $\mathrm{Bcl}-2$. Soluble $\mathrm{Cr}(\mathrm{VI})$ is reduced within cells by reductive agents including ascorbic acid, glutathione and cysteine generating a diverse range of genetic lesions. Some forms of $\mathrm{Cr}$ damage act as physical barriers to DNA replication, transcription and promote $\operatorname{apoptosis}^{[45]}$.

Other researchers ${ }^{[46]}$ assumed that on exposure to a certain level of $\mathrm{Cr}$ (VI) capable of eliciting some manifestation of toxicity, some cells may pass through transient check point arrest and damage repair. But with irreparable damage, the cell mostly undergo terminal growth arrest or apoptosis. However, other cells may acquire an intrinsic mechanism of death resistance through 
dysregulated DNA repair mechanisms and or dysregulated survival, and eventually lead to hyperplasia or even tumor cell formation instead of apoptosis. This assumption could explain the concomitant presence of apoptosis and hyperplasia in thyroid follicles of potassium dichromate induced hypothyroidism group. Follicular hyperplasia can be also explained by elevated level of TSH. Such hyperplasia was furtherly confirmed morphometrically by significant increase in the mean number of PCNA positive nuclei compared to the control group. Likewise, hyperplasia was confirmed in a former study by increased expression in $\mathrm{Ki} 67^{[19]}$.

In the same concern, cytoplasmic vacuolations seen in most of the follicular cells in the same group and discontinuous basement membranes seen in PAS stained sections could be attributed to ROS induced cellular membranes insults, which ultimately generate selfsustaining lipid peroxidation and enhanced transport of water and electrolytes into the cell ${ }^{[47]}$.

The multiple congested blood vessels detected in group III could be considered as a part of the inflammatory process that accompany chromium toxicity and the prolonged stimulation by elevated TSH. The latter might act as a growth factor for the thyroid tissue inducing an increase in stromal vascularity and neovascularization ${ }^{[48,19]}$.

The presence of multiple mast cells nearby blood vessels in the semithin sections in group III enforced this assumption. Mast cells act similarly to inflammatory cells and contribute to human diseases through the release of proinflammatory cytokines, chemokines; responsible for allergic reaction and proteases to induce inflammatory cell recruitment and matrix protein remodeling ${ }^{[40,49]}$. This explanation was furtherly supported by the association of increased mast cells with pathological conditions such as, inflammatory processes, fibrotic disorders, wound healing and neoplastic tissue transformation ${ }^{[50,51]}$. Other reporters ${ }^{[52]}$ related angiogenesis to mast cells as mast cells accumulate in many angiogenesis dependent situations like rheumatoid arthritis, ovulation, wound healing and tissue repair. In addition, several mast cell mediators are angiogenic and regulate endothelial cell proliferation and function. Other mast cell products such as tryptase degrade connective tissue matrix to provide space for neovascular sprouts. Moreover, the presence of mast cells in potassium dichromate induced hypothyroidism group could be attributed to their regulatory role in the process of thyroid hormone secretion and in thyroid gland activity. The number of mast cells in thyroid tissue was proved, in former study, to be related to TSH level. Their number increased greatly following elevated TSH level in rats kept on a low iodine diet and propylthiouracil ${ }^{[53]}$. In addition, other studies ${ }^{[54,55]}$ suggested that TSH could promote the release of serotonin from thyroid mast cells. Serotonin in turn, could activate thyroid follicular cells by enhancing them to extend pseudopodia and engulf thyroglobulin from the follicular lumen.

The current study assumed that withdrawal of potassium dichromate in the recovery group (group IV) resulted into minimal functional and histological improvement. This assumption was supported by the non significant differences in the mean values of T3, T4 and TSH in group IV versus group III and the significant differences versus group I indicating persistent hypothyroidism. Also examination of thyroid sections which revealed histopathological changes comparable to that of potassium dichromate group. Further enforcement came from morphometric measurements of this group where the mean values of diameter of thyroid follicles, height of follicular cells and number of PCNA positive nuclei were significantly increased versus group I with non significant differences versus group III. In addition to, a significant decrease in the mean area percent of colloid versus group I with a non significant difference versus group III. These results are consistent with that of thyroid function test. Stress exerted on the follicular cells by the toxic effect of potassium dichromate just started to decline following its withdrawal and, the highly elevated TSH just started to fall in this group leading to minimal histological improvement. Prolonged recovery duration might be needed for functional and histological improvement.

By contrast, the mean values of $\mathrm{T} 3$ and $\mathrm{T} 4$ were significantly increased and the mean value of TSH was significantly decreased in group V compared to groups III and IV but still with significant differences versus control group. These results suggested better improvement in the thyroid function with curcumin. Moreover, there was an obvious histological improvement compared to group III and group IV. As, most of the follicles were lined with a single layer of apparently normal follicular cells. Only, few cells in some follicles were still vacuolated with dark pyknotic nuclei. In addition, most of the thyroid follicles were filled with PAS positive colloid with normal peripheral vacuolations. This was established by morphometry that proved a significant decrease in the mean values of follicular diameter and follicular cell height and a significant increase in the mean area percent of colloid compared to groups III and IV with non significant differences versus group I.

These findings could be attributed to the protective effect of curcumin due to its antioxidant and anti-inflammatory properties leading to regression of histological alterations caused by potassium dichromate much more rapidly and more effectively than in the recovery group. This assumption was confirmed in a previous study ${ }^{[56]}$; whereas treatment of methimazole induced hypothyroidism with turmeric extract increased the antioxidant defense of the cells and attenuated injurious effects of ROS. Further support came from another study ${ }^{[57]}$ in which treatment of 
sodium chlorate induced hypothyroidism with curcumin resulted in significant decrease in plasma superoxide anion level compared to non-treated group. Therefore, curcumin was considered a bifunctional antioxidant; exerting direct effects by scavenging ROS and indirect effects by inducing the expression of antioxidant enzymes ${ }^{[34,58,59]}$.

The anti-inflammatory properties of curcumin was linked to its capability to interact with numerous molecular targets involved in inflammation. It modulates the inflammatory response by down-regulating the activity of specific kinases, cyclooxygenase-2, lipoxygenase, and inducible nitric oxide synthase enzymes. It also, inhibits the production of the inflammatory cytokines, tumor necrosis factor-alpha, interleukins and monocyte chemoattractant $\operatorname{protein}^{[50,61]}$.

Additionally, examined thyroid follicles from curcumin and potassium dichromate group revealed neither signs of hyperplasia nor hypertrophy and was confirmed morphometrically by a significant decrease in the mean number of PCNA positive nuclei compared to groups III and IV and a non significant difference versus control. This could be attributed to the anti-proliferative effect of curcumin exerted through its inhibitory effect on the activity of protein kinases as protein kinase $\mathrm{C}$ and on the mitogenic effect of growth factor signals in hypertrophic cells. These enzymes play a key role in signal transduction which leads to thyroid cell proliferation ${ }^{[20,62]}$. Moreover, curcumin can inhibit proliferation of abnormal and tumor cells through DNA damage and arrest at various phases of the cell cycle leading to apoptosis ${ }^{[63,64]}$.

\section{CONCLUSION}

Exposure of rats to potassium dichromate resulted into hypothyroidism and thyroid tissue damage that was slightly recovered after potassium dichromate withdrawal. Curcumin administration has proven to protect thyroid gland histological structure and functions against potassium dichromate damage. Therefore, concomitant intake of curcumin is recommended for factory workers exposed to potassium dichromate.

\section{CONFLICT OF INTEREST}

There are no conflicts of interest.

\section{REFERENCES}

1. Ayuob NN, El-Shitany NA, Alamae MN. Thymoquinone protects against hypothyroidisminduced cardiac histopathological changes in rats through a nitric oxide/antioxidant mechanism. Biomedical Research 2016; 27: 93-102.

2. Hayat NQ, Tahir M, Munir B, Sami W. Effect of methimazole-induced hypothyroidism on histological characteristics of parotid gland of albino rat. J Ayub Med Coll Abbottabad 2010; 22: 22-7.

3. Golden SH, Robinson KA, Saldanha I, Anton B, Ladenson PW. Clinical review: Prevalence and incidence of endocrine and metabolic disorders in the United States: a comprehensive review. J Clin Endocrinol Metab 2009; 94: 1853-78.

4. Chakrabarti SK Ghosh S, Banerjee S, Mukherjee S, Chowdhury S. Oxidative stress in hypothyroid patients and the role of antioxidant supplementation. Indian Journal of Endocrinol Metab 2016; 20: 674-678.

5. Nanda N. Oxidative stress in hypothyroidism. Int J Clin Exp Physiol 2016; 3: 4-9.

6. El Bakry RH, Tawfik SM. Histological study of the effect of potassium dichromate on the thyroid follicular cells of adult male albino rat and the possible protective role of ascorbic acid (vitamin C). JMAU 2014; 2: 137-50.

7. Nudler S, Quinteros F and Miler E. Chromium VI administration induces oxidative stress in hypothalamus and anterior pituitary gland from male rats. Toxicol Lett 2009; 185: 187-92.

8. Abu El-Saad AM, Abdel-Moneim AM, AbdelKarim HM. N-acetylcysteine an allium plant compound protects against chromium (VI) induced oxidant stress and ultrastructural changes of pancreatic beta-cells in rats. J Med Plant Res 2010; 4: 2290-97.

9. Mahmood T, Qureshi IZ, Iqabi MJ. Histopathological and biochemical changes in rat thyroid following acute exposure to hexavalent chromium. Histol Histopathol 2010; 25: 1355-70.

10. El-Mahalaway AM, Salem MM, Mousa AM. The effect of potassium dichromate on convoluted tubules of the kidney of adult male albino rats and the possible protective role of ginseng: a histological and immunohistochemical study. Egypt J Histol 2015; 38: 157-67.

11. El Saied AA, Fetouh FA, Albasha MO. Nephroprotective effects of curcumin, rosemary and propolis against gentamicin induced toxicity in guinea pigs: morphological and biochemical study. Am J Clin Exp Med 2014; 2: 28-35.

12. Kim SK, Seok H, Park HJ, Jeon HS, Kang SW, Lee BC, Jooil Yi, Song SY, Lee SH, Kim YO, Chung J. Inhibitory effect of curcumin on testosterone 
induced benign prostatic hyperplasia rat model. BMC Complement Altern Med 2015; 15: 27-.

13. Epstein J, Sanderson IR, Macdonald TT. Curcumin as a therapeutic agent: the evidence from in vitro, animal and human studies. Br J Nutr 2010; 103: 1545-57.

14. Darvesha AS, Aggarwal BB, Bishayee A. Curcumin and liver cancer: a review. Curr Pharm Biotechnol 2012; 13: 218-28.

15. Pandya U, Saini MK, Jin GF, Awasthi S, Godley BF, Awasthi YC. Dietary curcumin prevents ocular toxicity of naphthalene in rats. Toxicol Lett 2000; 115: 195-204.

16. Somanawat K, Thong-Ngam D, Klaikeaw N. Curcumin attenuated paracetamol overdose induced hepatitis. World J Gastroenterol 2013; 19: 1962-7.

17. Deraz EM, Abd-Elhamid AM, Fahmi AN. Histological and ultrastructural study of the effect of potassium dichromate with evaluation of potential protective role of vitamin $\mathrm{C}$ on submandibular salivary gland of rats. J Am Sci 2016; 12: 84-90.

18. Qureshi IZ, Mahmood T. Prospective role of ascorbic acid (vitamin C) in attenuating hexavalent chromium-induced functional and cellular damage in rat thyroid. Toxicol Ind Health 2010; 26: 349-59.

19. Hassanin KM, Abd El-Kawi SH, Hashem KS. The prospective protective effect of selenium nanoparticles against chromium-induced oxidative and cellular damage in rat thyroid. International $\mathrm{J}$ Nanomedicine. 2013; 8: 1713-20.

20. Papiez MA, Kaja M, Gebarowska A. Agedependent different actions of curcumin in thyroid of rat. Folia Histochem. Cytobiol 2008; 46: 205-11

21. Pourghasem M, Nasiri E, Shafi H. Early renal histological changes in alloxan-induced diabetic rats. Int J Mol Cell Med 2014; 3: 11-15.

22. Hadie S, Abdul Manan H, Abdulla S. Thyroid gland resection in euthanized rat. A practical guide. Int Med J 2013; 20: 1-4.

23. Kiernan J. Histological and histochemical methods: theory and practice. 3rd ed. London,
New York and New Delhi: Arnold publisher; 2001. pp. 111-162.

24. 24- Kerr JB, Duckett R, Myers M Britt KL, Mladenovska T, Findlay JK. Quantification of healthy follicles in the neonatal and adult mouse ovary evidence for maintenance of primordial follicle supply. Reproduction 2006; 132(1): 95-109.

25. Bancroft J, Gamble M. Theory and practice of histological techniques. Staining methods. 7th ed. Edinburgh, London, Madrid, Melbourne, New York and Tokyo: Churchill Livingstone; 2008. pp. 263-325.

26. Hayat MA. Chemical fixation. In: Principles and techniques of electron microscopy: biological applications. 4th ed. Edinburg, UK: Cambridge University Press. 2000. pp.4-85.

27. Dykstra MJ and Reuss LE. Staining methods for semithins and ultrathins. In: Biological electron microscopy, theory, techniques and troubleshooting. 2nd ed. Kluwer Academic Publishers/Plenum Publishers. 2003. pp.175- 196.

28. Emsley R, Dunn G, White IR. Mediation and moderation of treatment effects in randomised controlled trials of complex interventions. Stat Methods Med Res. 2010; 19: 237-270.

29. Dorafshani MM, Jalali M, Nikravesh MR, Ebrahimzadeh AR. Study of the effect of hypothyroidism on the apoptotic index in rat ovarian follicles, using the tunel technique. ASJ 2013; 10: 25-35.

30. Bagchi D, Stohs SJ, Downs BW, Bagchi M, Preuss HG. Cytotoxicity and oxidative mechanisms of different forms of chromium. Toxicology 2002; 180: 5-22.

31. Banu S, Stanley J, Lee J, Stephen S, Arosh J, Hoyer P, Burghardt R. Hexavalent chromium-induced apoptosis of granulosa cells involves selective subcellular translocation of Bcl-2 members, ERK12/ and p53. Toxicol Appl Pharmacol 2011; 251: 253-66.

32. Xiao F, Chen D, Luo L, Zhong X, Xie Y, Zou L, Zeng M, Guan L and Zhong C. Time-order effects of vitamin $\mathrm{C}$ on hexavalent chromium-induced mitochondrial damage and DNA-protein cross links in cultured rat peripheral blood lymphocytes. Mol Med Rep 2013; 8: 53-60. 
33. Nabavi SF, Moghaddam AH, Nabavi SM, Eslamic S. Protective effect of curcumin and quercetin on thyroid function in sodium fluoride intoxicated rats. Fluoride 2011; 44: 147-52.

34. Garcia-Nino WR, Tapia E, Zazueta C, ZatarainBarron ZL, Hernandez-Pando R, VegaGarcia CC, Pedraza-Chaverri J. Curcumin pretreatment prevents potassium dichromateinduced hepatotoxicity, oxidative stress, decreased respiratory complex I activity, and membrane permeability transition pore opening. Evid. Based Complement. Altern Med 2013; ID 424692: 19 pages.

35. Dunn D, Turner C. Hypothyroidism in Women. Nursing for Women's Health 2016; 20: 93 - 98.

36. Martini FH, Timmons MJ, Tallitsch RB, Ober WC, Garrison CW, Kathleen Welch K, Hutchings RT. The endocrine system. In: Human anatomy. 7th ed, Benjamin Cummings. 2012. pp. 507-28.

37. Harvey PW, Rush KC, CockBurn A. Endocrine and hormonal toxicology. 6th ed, John Wiley and Sons Ltd, Chichester, New York, Weinheim, Brisbane, Singabore, Toronto, England. 1999. pp.1-568.

38. Enemali FU, Hambolu JO, Alawa JN, Anosike IV. Gross anatomical, histological and histochemical studies of thyroid glands of African giant rat. JPBS 2016; 11: 40-3.

39. Sosi-Jurjevi B, Filipovi B, Milo sevi B, Nestorovi N, Negi , SekuliM. Effects of ovariectomy and chronic estradiol administration on pituitarythyroid axis in adult rats. Life Sci 2006; 79: 890-7.

40. El-Rouby NM. A histological study on the effect of diclofenac sodium (declophen) administration on thyroid follicular cells of albino rats. Egypt $\mathbf{J}$ Histol 2010; 33: 213-23.

41. Hayat MA. Semithin sections. In: Basic techniques for transmission electron microscopy 4th ed. Elsevier. 2012. pp. 164-169.

42. Mescher AL. The endocrine glands. In: Junqueira's basic histology, text and atlas, chapter 20. 12th ed., Mc Graw Hill, Singapore. 2010. PP. 348-70.

43. Patil V, Dhurvey V. Exposure to sodium fluoride affects thyroid follicular cells in albino rats. IJPAES 2015; 5: 56-61.

44. Rhouma K, Marouani N, Tebourbi O. Effects of hexavalent chromium on reproductive functions of male adult rats. Reprod Biol 2012; 12: 119-33.

45. Quinteros F, Machiavelli L, Miler E, Cabilla J, Duvilanski B. Mechanisms of chromium (VI)induced apoptosis in anterior pituitary cells. Toxicology 2008; 249: 109-15.

46. Nickens KP, Patierno SR, Ceryak S. Chromium genotoxicity: A double-edged sword. Chem Biol Interact 2010; 188: 276-288.

47. Abdul-Hamid M, Moustafa N. Protective effect of curcumin on histopathology and ultrastructure of pancreas in the alloxan treated rats for induction of diabetes. The Journal of Basic and Applied Zoology 2013; 66: 169-79.

48. Standring S. Neck. In: Gray's anatomy. The anatomical basis of clinical practice, chapter 28 . 40th ed, Churchill Livingstone Elsevier, London UK. 2008. pp. 435-66.

49. Xu J, Shi G. Emerging role of mast cells and macrophages in cardiovascular and metabolic diseases. Endocrine Rev 2012; 33:71-108.

50. Bischoff S, Sellge G. Mast cell hyperplasia: role of cytokines. Int Arch Allergy Immunol 2002; 127: 118-22.

51. Saglam B, Cikler E, Zeybek A, Cetinel S, Ercan F, Sener G. Protective effects of 2-mercaptoethane sulfonate (MESNA) on protamine sulfate induced bladder damage. Marmara Medical J 2005; 18: 6-12.

52. Hiromatsu Y, Toda S. Mast cells and angiogenesis. Microsc. Res. Tech 2003; 60: 64-9.

53. Motta p. A structural pathology of the thyroid gland. In Ultrastructure of endocrine cells and tissues: Electron microscopy of biology and medicine. Springer Science and Business Media, 2012. pp. 286-289.

54. Melander A, Sundler F. Significance of thyroid mast cells in thyroid hormone secretion. Endocrinology Mar 1972; 90: 802-807.

55. Melander A, Hakanson R, Westgren U, Owman C, Sundler F. Significance of thyroid mast cells in the regulation of thyroid activity. Agents Actions 1973; 3:186.

56. Deshpande UR, Joseph LJ, Patwardhan UN, Samuel AM. Effect of antioxidants (vitamin C, 
E and turmeric extract) on methimazole induced hypothyroidism in rats. IJEB 2002; 40: 735-8.

57. Sourour DA. Curcumin induces apoptosis in thyroid cells in rats: possible role of caspase 3 . IJAR 2014; 2: 790801-.

58. Ak T, Gülcin I. Antioxidant and radical scavenging properties of curcumin. Chem Biol Interact 2008; 174: 27-37.

59. Dinkova-Kostova AT, Talalay P. Direct and indirect antioxidant properties of inducers of cytoprotective proteins. Molecular Nutrition and Food Research 2008; 52: 128-38.

60. Goel A, Kunnumakkara AB, Aggarwal BB. Curcumin as "curecumin": from kitchen to clinic. Biochem Pharmacol 2008; 75: 787-809.

61. Jurenka JS. Anti-inflammatory properties of curcumin, a major constituent of curcuma longa: a review of preclinical and clinical research. Altern Med Rev 2009; 14: 141-53.

62. Youreva V, Kapakos G, Srivastava AK. Insulinlike growth-factor-1-induced PKB signaling and Egr-1 expression is inhibited by curcumin in A-10 vascular smooth muscle cells. Can J Physiol Pharmacol 2013; 91: 241-7.

63. Martín-Cordero C, López-Lázaro $\mathrm{M}$, Gálvez M, Ayuso MJ. Curcumin as a DNA topoisomerase II poison. J Enzyme Inhib Med Chem 2003; 18: 505-9.

64. Su CC, Lin JG, Li TM, Chung JG, Yang JS, Ip SW, Lin WC, Chen GW. Curcumin-induced apoptosis of human colon cancer colo 205 cells through the production of ROS, $\mathrm{Ca} 2+$ and the activation of caspase-3. Anticancer Res 2006; 26: 4379-89. 
الملخص العربى

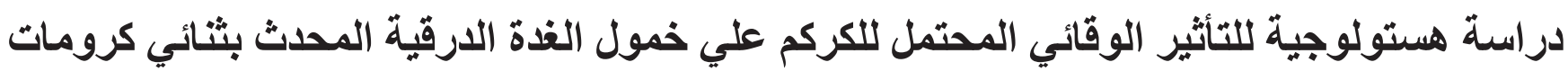
البوتاسيوم فى ذكور الجرذان البيضاء البالغة

\title{
جيهان إبراهيم أبو الفتوح، رحمة كمال الدين أبو النور، إيمان عباس فرج، وفاء عبد العظيم عبده بوغدادي التون،
}

\author{
قسم علم الأنسجة، كلية الطب، جامعة القاهرة ، القاهرة ، مصر
}

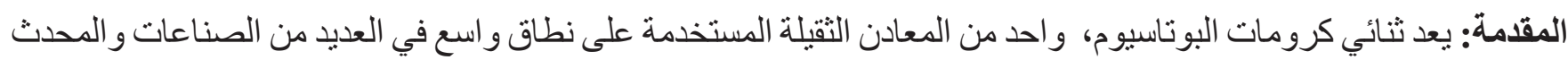

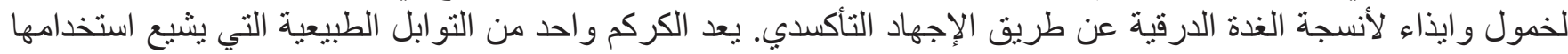

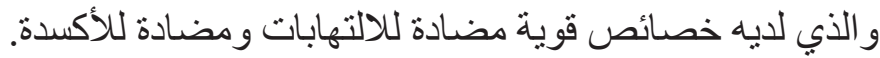
الهدف من البحث: اكتثاف التأثثر الوقائي المحتمل للكركم على خمول الغدة التهات الدرفية المحدث بثنائي كرومات البوتاسيوم في الجرذان البيضاء.

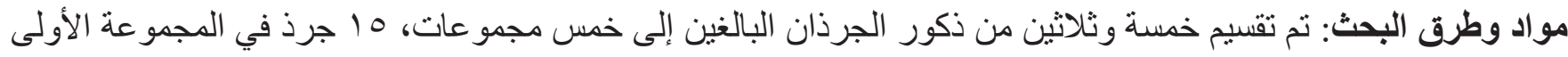

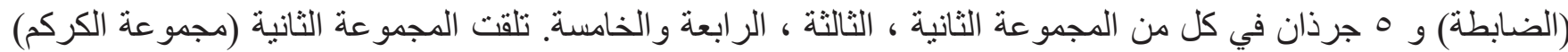

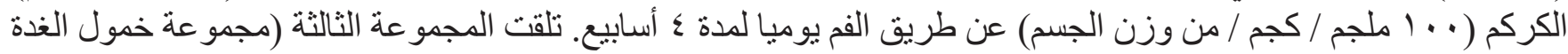



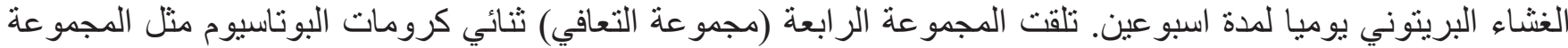

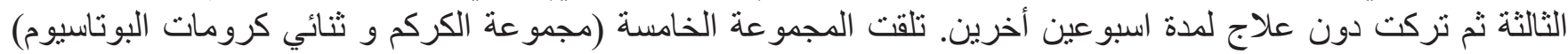

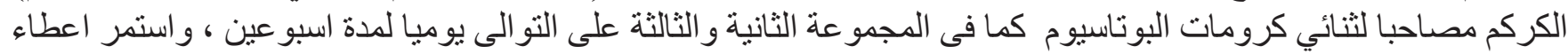

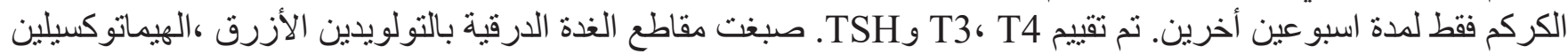

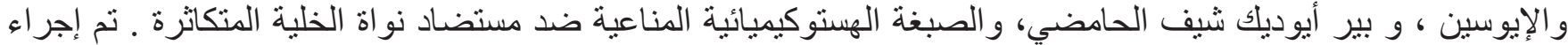
الدر اسات المترية الثكلية و الإحصائية.

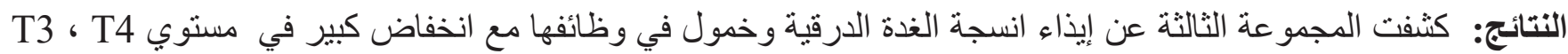

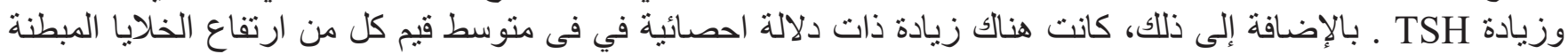

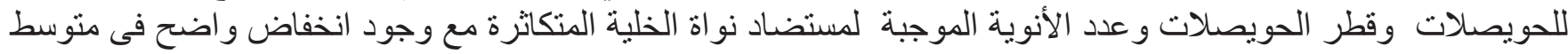

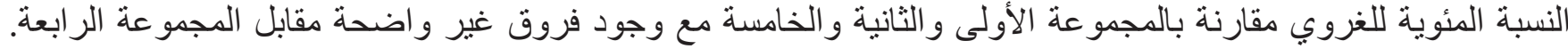
أظهرت المجمو عة الخامسة تحسن نسيجيا ومصليا واضحا مقارنة الأنة بالمجمو عة الثالثة و الر ابعة.

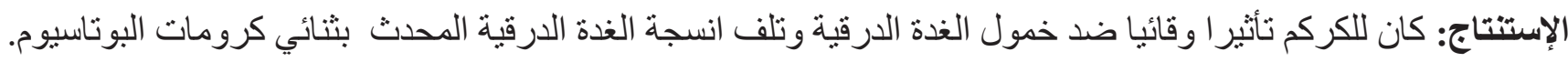

